$\mathrm{A} \int_{\text {ass }} \mathrm{H}$

Article history :

Received : 19.06.2014

Revised : 22.03.2015

Accepted : 08.04.2015

Members of the Research Forum

Associated Authors:

${ }^{1}$ Krishi Vigyan Kendra, SITAPUR

(U.P.) INDIA

${ }^{2}$ Krishi Vigyan Kendra, CHURU (RAJASTHAN) INDIA
Author for correspondence : OM SINGH

College of Horticulture, Rajmata Vijayaraje Scindia Krishi Vishwa Vidyalaya, GWALIOR (M.P.) INDIA Email : Omsingh1921@gmail.com
THEASIAN JOURNAL OF HORTICULTURE

Volume 10 | Issue 1 | June, 2015 | 45-48

Visit us -www.researchjournal.co.in

\title{
Juice blends - A way of utilization of under- utilized fruits
}

\section{OM SINGH, RICHA SINGH ${ }^{1}$ AND PRATIKSHA SINGH ${ }^{2}$}

ABSTRACT : The post-harvest shelf-life of maximum of fruits is very limited due to their perishable nature. In India more then 20-22 per cent of fruits are spoiled before utilization. Despite being the world's second largest producer of fruits, in India only 4 per cent of the total fruits produced are processed. Maximum amounts of fruit juices turn bitter after extraction due to conversion of chemical compounds. In spite of being under-utilized, the utilization of highly nutritive fruits and vegetables is very limited due to high acidity, astringency, bitterness and some other factors. While improving flavour, palatability and nutritive and medicinal value of various fruit juices such as aonla, mango, jackfruit, guava and jamun, used for juice blending. All these natural products are valued very highly for their refreshing juice, nutritional value, pleasant flavour and medicinal properties. Fruits are also a rich source of sugars, vitamins and minerals. However, some fruits have an off flavour and bitterness although they are an excellent source of vitamins, enzymes, and minerals. Therefore, blending of two or more fruit juices for the preparation of nutritive ready-to-serve (RTS), beverages is thought to be a convenient and economic alternative for utilization of these fruits. Moreover, one could think of a new product development through blending in the form of a natural health drink, which may also serve as an appetizer. The present investigation focuses on the blending of fruits, under-utilized fruits in appropriate proportions for the preparation of natural fruit based nutritive beverages.

KEY WORDS : Aonla, Mango, Guava, Jackfruit, Jamun, Under-utilized fruit, RTS, Nectar, Squash

HOW TO CITE THIS ARTICLE : Singh, Om, Singh, Richa and Singh, Pratiksha (2015). Juice blends - A way of utilization of under-utilized fruits. Asian J. Hort., 10(1) : 45-48. 